\title{
Induced floral heteromorphism in Petunia hybrida
}

\author{
S. G. KASHIKAR, A. S. KHALATKAR
}

Post-Graduate Department of Botany, Nagpur University Campus, Nagpur-440 010, India (Received: April 16, 1981)

\begin{abstract}
Floral heteromorphism induced in Petunia hybrida with several chemical mutagens and gamma-radiation is discussed. Potentials of these mutagens in inducing various forms are described. The effect of heteromorphism on flower production, pollen sterility and seed set besides cross and self compatibilities between different heteromorphic forms have also been reported.
\end{abstract}

\section{INTRODUCTION}

Floral heteromorphism has been difined as a condition where a species occurs in two or three floral forms, differing in their style and stamen heights (Bahadur and Reddy 1978). In Solanaceae several species of Solanum have been reported showing stylar heteromorphism (Martin 1972, Hossain 1973, Bahạdur et al. 1976, Reddy and Bahadur 1977). In the present investigations, various mutagens were observed to induce heterostyly in $P$. hybrida.

\section{MATERIAL AND METHODS}

The dry seeds of a white-flowering, self compatible strain of Petunia hybrida Hort., were treated with ethyl methane sulfonate (EMS), diethyl sulfate (DES), N-methyl-N-nitro-N-nitrosoquanide (NMG), sodium azide (SA) and ethylene imine (EI). In addition to these treatments, dry seeds were iraradiated in 60-Co Gamma cell. The treated seeds were utilised to raise the $M_{1}$ population. The first three capsules of each $M_{1}$ plant were used for raising the $M_{2}$ generation. The population so obtained was screened for staminal and stylar heteromorphism. For each mutangen at least 5000 plants were screened. The length of the style, stamens and corolla tube was measured in $\mathrm{mm}$ from all the flowers. Pollen sterility in these plants 
was determined by screening pollen grains from freshly dehisced anthers with acetocarmine glycerine mixture. The degree of incompatibility was determined in crosses between control and heteromorphic flowers. The seed set per capsule in these flowers was investigated.

\section{RESULTS}

The data on the length of the styles and stamens in different flower types are given in Table 1. In the control, the mean length of the style as well as the largest pair of stamens was $44 \mathrm{~mm}$. The length of the style in these flowers was $98.6 \%$ of the total length of the corolla tube. In the long style flowers, the style was nearly $8 \mathrm{~mm}$ longer than the stamens and its length was more than the length of the corolla tube. The length of the stamen was $26 \mathrm{~mm}$. Whereas, in mid style type, the length of the style was $39 \mathrm{~mm}$ and it was $93 \%$ of the length of the corolla tube. The average length of the stamen was $43 \mathrm{~mm}$. In the short style type, the style was reduced to $25 \mathrm{~mm}$, while the stamens were $34 \mathrm{~mm}$. The style in this flower was $54,3 \%$ of the corolla tube length.

Table 1

Length of styles and stamens in different flower types (in $\mathrm{mm}$ )

\begin{tabular}{|c|c|c|c|c|c|}
\hline \multirow[t]{2}{*}{ Nature of style } & \multicolumn{2}{|c|}{ Length of style } & \multirow{2}{*}{$\begin{array}{c}\text { Style as per- } \\
\text { cent of corol- } \\
\text { la tube }\end{array}$} & \multicolumn{2}{|c|}{$\begin{array}{l}\text { Length of the longest } \\
\text { pair of stamens }\end{array}$} \\
\hline & range & mean & & range & mean \\
\hline Control & $40-45$ & $44 \pm 0.2$ & 98.6 & $38-45$ & $44 \pm 0.4$ \\
\hline Long style & 28-39 & $34 \pm 0.1$ & 131.6 & $17-31$ & $26 \pm 0.3$ \\
\hline Mid style & $36-41$ & $39-0.2$ & 93.0 & $40-45$ & $43+0.5$ \\
\hline Short style & $23-30$ & $25+0.1$ & 54.3 & $33-36$ & $34 \pm 0.4$ \\
\hline
\end{tabular}

The data on the frequency of the heteromorphic flowers in different mutagenic treatments is given in Table 2. Almost all the mutagens used in the present study induced plants with long styles. The frequency

Table 2

EMS, DES, NMG, SA, EI and gamma radiation induced frequencies of heteromorphic flowers in $\mathbf{M}_{2}$ generation (pooled data)

\begin{tabular}{|l|c|c|c|}
\hline \multicolumn{1}{|c|}{ Mutagens } & $\begin{array}{l}\text { Plants with long } \\
\text { style flowers, \% }\end{array}$ & $\begin{array}{l}\text { Plants with mid } \\
\text { style flowers, \% }\end{array}$ & $\begin{array}{l}\text { Plants with short } \\
\text { style flowers, \% }\end{array}$ \\
\hline Control & - & - & - \\
EMS & 2.4 & 0.85 & 0.15 \\
DES & 1.4 & 0.40 & 0.05 \\
NMG & 4.1 & 0.60 & - \\
SA & 1.0 & - & 0.25 \\
EI & 1.0 & - & - \\
Gamma rays & 0.2 & - & - \\
\hline
\end{tabular}


of long style flowers was highest after NMG treatment and second highest after EMS. The mid style type of plants was induced by only a few mutagens like EMS, NMG and DES. The frequency of this type was much lower than that of long type flowers. Similarly, the short style flowers were induced at very low frequency by SA, NMG and DES, respectively.

The relationship between the type of flower, number of flowers producec in 30 days, pollen sterility and seed set is apparent from the data presented in Table 3. The control had 3\% sterile pollen and set abundant seeds. The long style flowers were of three categories; in one group, $27.1 \%$ pollen was sterile and had $50.1 \%$ seed set. In another group, the pollen sterility was $36.4 \%$ and it was self as well as cross incompatible. The third group had $7.3 \%$ sterility and was cross compatible and self incompatible. The mid style type had $17.3 \%$ sterile pollen grains and had reduced set compared to control. However, the sterility was $24.6 \%$ in short style flowers and it had its reflection in the considerably lower seed set. In all these types, maximum flowers were produced in the long style plants followed by the mid-types. Short style plants produced least number of flowers compared to control.

Table 3

Number of flowers produced, percentage pollen sterility and seed set, in different flower types

\begin{tabular}{|l|c|c|c|}
\hline Fower form & $\begin{array}{c}\text { Number of } \\
\text { flowers produced } \\
\text { in one month }\end{array}$ & $\begin{array}{c}\text { Pollen } \\
\text { sterility, \% }\end{array}$ & $\begin{array}{c}\text { Seed set per } \\
\text { capsule }\end{array}$ \\
\hline Control & $41 \pm 2$ & $3.0 \pm 0.2$ & $100.0 \pm 0.0$ \\
Long style (a) & $71 \pm 5$ & $27.1 \pm 0.4$ & $50.1 \pm 1.3$ \\
& $106 \pm 4$ & $36.4 \pm 0.3$ & 0 \\
Mid style (c) & $96 \pm 4$ & $7.3 \pm 0.1$ & $60.6 \pm 1.2$ \\
Short style & $43 \pm 3$ & $17.3 \pm 0.4$ & $56.5 \pm 1.4$ \\
& $30 \pm 1$ & $24.6 \pm 0.6$ & $14.3 \pm 1.0$ \\
\hline
\end{tabular}

The percent seed set per capsule in crosses between different flower types is given in Table 4 . When long style plants were selfed and crossed

Table 4

Number of seeds produced in crosses between different flower types

\begin{tabular}{|l|r|r|c|c|c|c|}
\hline \multirow{2}{*}{\multicolumn{1}{|}{$+\widehat{\sigma}^{*}$}} & \multirow{2}{*}{ Control } & \multicolumn{3}{c|}{ Long style } & \multirow{2}{*}{ Mid style } & \multirow{2}{*}{ Short style } \\
\cline { 3 - 5 } & & $\mathrm{a}$ & $\mathrm{b}$ & $\mathrm{c}$ & & \\
\hline Control & $100.0 \pm 0.0$ & $56.9 \pm 1.4$ & 0 & $60.6 \pm 1.2$ & $45.9 \pm 0.9$ & $41.5 \pm 1.3$ \\
Long style & $50.8 \pm 1.0$ & $50.1 \pm 1.3$ & 0 & 0 & $54.0 \pm 1.0$ & $35.7 \pm 0.7$ \\
Mid style & $37.6 \pm 0.8$ & $31.2 \pm 1.0$ & 0 & $37.6 \pm 1.3$ & $56.5 \pm 1.4$ & $29.6 \pm 0.8$ \\
Short style & $30.0 \pm 0.7$ & $23.2 \pm 1.0$ & 0 & $52.3 \pm 0.8$ & $31.3 \pm 1.1$ & $14.3 \pm 1.0$ \\
\hline
\end{tabular}


with control and short style, three groups of this type emerged. In the first group, on selfing there was seed set, in the second, there was no seed set in any of the crosses, whereas in the third group, there was no seed set on selfing but when it was crossed with control and short style there was good seed set, indicating self incompatibility and cross compatibility. Plants with mid style flowers were found to set seeds on selfing which points to self compatibility. The short style flowers, set reduced number of seeds indicating partial self compatibility. These plants set a good amount of seeds on crossing with control and long style types.

\section{DISCUSSION}

The induced heteromorphism in the present investigation include in addition to the extreme cases of long and short style flowers, a third condition called mid-style in which the length of the style was such that the stigma was placed between the two tiers of the stamens and therefore was comparable to the tristyly described in Lythrum junceum of the family Lythraceae (Dulberger 1970), in which three contrasting levels of the style and stamen were found. The tristyly has been reported to occur in the species belonging to Pontendriaceae, Ammaryllidaceae, Oxalidaceae and Lythraceae (Nettancourt 1977). The long and short style flowers are comparable to the pin and thrum type in Primula (Darwin 1877). In our investigations all the three conditions existed on distinct individuals.

The long style condition had shorter styles than the control flowers, however, due to the reduction in length of the corolla tube and the stamens, it protruded out. Therefore this condition appeares to be linked with the length of the corolla tube and stamens.

The heterostylous conditions, where the stigma is exerted beyond the stamen fold before pollen maturity, may provide a means of hybridisation without the necessity of hand emasculation. Currence (1944) reported a semi-sterile plant resulting from unusually long styles and proposed the incorporation of this character into acceptable female parents for tomato hybrid seed production. Several workers (Rick 1958, Honma and Buk ovac 1966) agree that at least part of the control of sigma exsertion is genetic. Williams (1961) concluded that stigma exsertion was controlled by a strong genetic component with incomplete dominance.

The mid-style flower had in reality longer style than the long style condition, however, as the corolla tube was like control flower the reduction in the length of the style compared to control brought it to the mid level. In these flowers, although the stames were at a little lower level than control, they were in two tiers of $2+3$ configuration instead of $2+2+1$.

The short style conditions had no effect on the corolla tube. Although, both the style and stamens had reduced length, the reduction was pronounced in the style. Comparison between the two extreme conditions indi- 
cates considerable reduction in the length of the stmens in pin while that of the style in thrum type.

Heterostyly did not show a tight linkage with incompatibility. This condition without any incompatibility was reported by Vuilleumier (1967) in several genera. According to him, heteromorphism which lacks incompatibility, may still strongly promote allogamy due to the mechanism of insect pollination. Heterostyly, promoting cross pollination, has been reported to have induced with gibberellins in tomatoes (Bukovac and Honma 1967).

In the present investigations, at least in certain cases, the induced heteromorphism appears to have developed in response to high sterility. One group of the long style plants failed to produce seeds, even after repeated cross and self pollinations. In this case, the long style condition could be associated with female sterility. Bahadur et al. (1976) have reported heterostyly associated with female sterility in Solanum melangena. The other group of long style plants had $27.1 \%$ sterile pollen grains. However, the plants were self compatible. The third group had $7.3 \%$ sterility and it was self incompatible and cross compatible. The association of male sterility and heterostyly was reported in Carissa grandiflora (Schroeder 1951)., Relationship between female sterility and flower production female sterility, produced maximum number of flowers.

Although the mid style plant had $17.3 \%$ sterile pollen grains, they were self as well as cross compatible. The short style plants had $24.6 \%$ sterility, however, the seed set was lower on selfing, it was improved on cross pollination with control, indicating partial incompatibility. Briggs (1964), has reported self compatible short style flowers in Darwinia.

In the present investigations, of the several mutagens tried. EMS and DES induced all the three conditions, whereas NMG and SA could induce only two. EI and gamma radition treatments resulted in only one type. NMG induced maximum frequency of plants with long style. The results indicate the possibilities of mutating genes controling the style and the stamen lengths in $P$. hybrida. These genes appear to be differentially sensitive to the mutagens used in the study.

\section{REFERENCES}

Bahadur B., Reddy N. P., 1978. Incompatibility Newsletter 10: 43-68.

Bahadur B., Reddy N. P., Venkateshwarlu T., 1976. Solanacae Newsletter 3: 14-17.

Briggs B. G., 1964. Evolution 18: 292-303.

Bukovac M. J., Honma S., 1967. Proc. Amer. Soc. Hort. Sci. 91: 514-520.

Currence T. M., 1944. Proc. Amer. Soc. Hort. Sci. 44: 403-406.

Darwin C., 1877. The different forms of flowers on the plants of the same species. John Murray, pp. 121-127.

Dulberger R., 1970. New Phytologist 69-751-759.

Honma S., Bukovac M. J., 1966. Euphytica 15: 362-364.

Hossain M., 1973. Bot. J. Linn. Soc. 66: 219-302. 
Martin F. W., 1972. Phyton 29: 127-134.

Nettancourt D. de., 1977. Incompatibility in angiosperms. Monograph on Theorectical and Applied Genetics 3, Springer Verlag, pp. 7-54.

Reddy N. P., Bahadur B., 1977. Geobios 4: 103-105.

Rick C. M., 1958 Econ. Bot. 12: 346-367.

Schroeder C. A., 1951. Proc. Amer. Hort. Sci. 57: 419-422.

Vuilleumier B. S., 1967. Evolution 21: 210-226.

Williams W., 1961. Tomato Genetics Coop. Res. Notes. Report 11: 27-28.

\section{Indukowany heteromorfizm kwiatów Petunia hybrida}

\section{Streszczenie}

Kilkoma mutagenami chemicznymi i promieniami gamma indukowano heteromorfizm kwiatów Petunia hybrida. Opisano skuteczność działania tych mutagenów w wytwarzaniu różnych form kwiatów. Badano również zależność między heteromorfizmem a wytwarzaniem kwiatów, sterylnością pyłku i wielkością zbioru nasion. Ponadto określano stopień zgodności, krzyżując kwiaty kontrolne $\mathrm{z}$ heteromorficznymi. 